\title{
Performance Evaluation of Motor Insurance Companies: Panel Data Evidence from Nigeria
}

\author{
G. U. Ugwuanyim¹, D. E. Onwuegbuchunam², D. C. Bartholomew ${ }^{1}$, C. C. Anikpe ${ }^{3}$ \\ ${ }^{1}$ Department of Statistics, Federal University of Technology, Owerri, Nigeria \\ ${ }^{2}$ Department of Maritime Management Technology, Federal University of Technology, Owerri, Nigeria \\ ${ }^{3}$ Department of Transport Management Technology, Federal University of Technology, Owerri, Nigeria \\ Email: don@futo.edu.ng
}

How to cite this paper: Ugwuanyim, G.U., Onwuegbuchunam, D.E., Bartholomew, D.C. and Anikpe, C.C. (2021) Performance Evaluation of Motor Insurance Companies: Panel Data Evidence from Nigeria. Journal of Transportation Technologies, 11, 325-334. https://doi.org/10.4236/jtts.2021.113021

Received: March 30, 2021

Accepted: May 16, 2021

Published: May 19, 2021

Copyright (c) 2021 by author(s) and Scientific Research Publishing Inc. This work is licensed under the Creative Commons Attribution International License (CC BY 4.0).

http://creativecommons.org/licenses/by/4.0/

\begin{abstract}
This paper evaluated performance of motor insurance companies in Nigeria. The objectives were to determine the following: 1) significant effects of claims settlements on motor insurance firms' earned premium; 2) differences in managerial/technological capabilities among the companies and 3) effects of policy (or time effect) on insurance firms' output within the study period. Panel data obtained for this study comprised operational data on premium earned and direct claims settlement by these companies over a period of six (6) years. Using panel data statistical models, we found that direct claims settlement negatively affected insurance companies' earned premium. Also, significant differences in technological and managerial capabilities were found to exist among the companies, though only one company exhibited this heterogeneity. Besides, there were no policy impacts (or time effect) on vehicle insurance firms' output in the study period. Policy implications of the results were discussed.
\end{abstract}

\section{Keywords}

Motor Insurance, Premium Earned, Claims Settlement, Managerial and Technological Performance, Fixed Effects Regression

\section{Introduction}

The insurance industry plays a very significant role in mobilization of investable resources. This is particularly true in developing economies, where financial systems are not sufficiently robust [1]. Insurance contracts provide a means of risk management in economic and public activity as well as in professional activity and private life [2]. Vehicle insurance (also known as car insurance, motor in- 
surance or auto insurance) for example, provides financial protection against physical damage and/or bodily injury resulting from traffic collisions. Motor Insurance companies accept consideration (or premiums) for the purpose of providing indemnity to a policyholder in event of loss, subject to the presumption that the policyholder follows and abides by all the terms and conditions prescribed in the contract. In this regard, volume of insurance policy contracts administered/sold can be directly related to volume of premium collected as consideration for indemnity provided. Thus, insurance firms' performance can be measured in terms of premium earned and indemnity provided (claims settlement) among other criteria.

Insurance began in the European shipping industry as a way to protect both merchants and shipowners from loss (Ryskamp [3]). The history of the insurance industry in Nigeria could be traced to the British colonial trading companies that established agency offices in Nigeria on behalf of insurance companies in the UK (Augustine and Bamidele [4]). It started from 1921 when the Royal Exchange Assurance (Nigeria) Plc. was established in Nigeria [4]. It was not until 1958 that the first indigenous insurance company, the African Insurance Company Limited, was established. At independence in the year 1960, only four (4) out of the then twenty-five (25) firms in existence were indigenous. By 1976, the number of indigenous insurance companies had far surpassed that of foreign companies. As at September 2005, there were one hundred and four (104) insurance companies and four (4) reinsurance companies in existence before financial recapitalization reforms [5]. The indigenously owned insurance companies plagued by inadequate capital were unable to pay claims as at when due. This inadequacy of capital factor coupled with lack of technical and managerial skills, poor insurance regulatory frameworks, brought about crisis and intense apathy to insurance purchase in Nigeria. The financial re-capitalization reforms, meant to improve the sector reduced the pre-reform number of firms from 104 to 49 [6].

\subsection{The Research Problem and Justification of Study}

The demand for general insurance in Nigeria had been low $(0.68 \%$ according to KPMG [7]) as insurance firms were beset with challenges ranging from inadequacy of capital, inability to settle claims to lack of technical and managerial skills, and poor insurance regulatory frameworks (see Cheruiyot [8] \& Adewale [9]). These challenges engendered apathy to insurance purchase and hence affected the industrys' output. Specifically motor insurance (especially Third Party policy) though mandatory for vehicle owners but yet experienced low demand. As Nigeria Insurance Association (NIA [10]) posits, about 9.5 out of 12 million registered vehicles in Nigeria do not have insurance cover. Thus, in order to restructure the insurance sector and increase uptake of insurance services, the Federal government of Nigeria through its regulatory agency-the National Insurance Commission (NAICOM), introduced re-capitalization policy. This was meant to improve capital base of insurance sector, improve market penetration and earned 
premium [6].

A number of papers have investigated performance of insurance firms. For example, Cummins \& Venard [11] examined global developments and local factors affecting insurance markets. Some of the factors include deregulation, globalization of insurance institutions, intensified competition, electronic commerce, bank assurance and the emergence of new risks. Most studies relate insurance companies' performance and sustainability to the companies' capacity to manage claims (examples include Satish [12], Ofori \& Attah [13], Yusuf, Ajemunigbohun \& Alli [14], Santolino and Boucher [15], Singh [16], Rose [17] and Yong [18]). Other authors assert that earned premiums have a major impact on performance of insurance companies (see Kumaga, Kuttu \& Asuming [19]). Sukono et al. [20] maintain that performance can be enhanced through application of claims risk and premium predictive models. Their work is consistent with Segovia-Vargas et al. [21] who posit that risk classification models can be used to manage performance. Excellent claims handling service is considered a differentiator that distinguishes insurance companies from their competitors [22]. However, Wairimu [23] finds weak underwriting standards as the highest challenge in the management of general insurance claims and hence should be eliminated through robust polices. Onwuegbuchunam, Ogwude \& Igboanusi [24] add that operating environment apart from efficient management of claims settlement and earned premium, impact on performance of marine insurance companies. These papers examined performance determining factors but did not account for differences in performance across firms and time impact of regulatory policy. The present paper extends existing literature by determining differences in managerial and technological capabilities among the studied companies and also seeks to establish whether reform policies have had an impact on their output over time. It is specifically an extension of the work of Onwuegbuchunam [24], but in this case, concentrates on motor insurance companies as unit of analysis.

\subsection{The Objectives of Study}

The specific objectives of this paper are to determine significant:

1) Effects of claims settlement on motor insurance companies' performance (performance is proxied by volume of premium collected) in Nigeria.

2) Differences in technological and managerial capabilities of motor insurance companies under study.

3) Time effect (or policy impact) on motor insurance companies' output within the study period.

\subsection{Hypotheses of the Study}

In order to actualize these objectives, the following null hypotheses will be tested:

1) There is no significant effect of claims settlement on motor insurance companies' performance in Nigeria.

2) There are no significant differences in the technological and managerial capabilities among the studied insurance companies in Nigeria. 
3) There is no significant time effect (or policy impact) on motor insurance companies' output in Nigeria in the study period.

The rest of this paper is divided into four sections namely: research methodology, data presentation and analyses results, conclusion and recommendations and references.

\section{Research Methodology}

This study was based on ex-post facto research design since the data employed were secondary in nature. The data comprised annual records on insurance premiums collected (throughputs) (N'000) and claims settled (N'000) by ten (10) insurance companies for the years 2010 to 2015. It is a short panel since it comprised few time periods and many observational units [25]. The companies considered here were purposively selected because they were the ones with complete data for the years under study. Therefore, inference would be based on these observational units. By combining time series of cross-section observations, panel data provide more information, more variability, less collinearity among variables, more degrees of freedom and more efficiency [26].

\subsection{Method of Data Analysis}

The data as stated in the preceding section is a balanced panel data with fixed effects since they were not randomly collected and each cross-sectional unit has the same number of observations. The fixed effects model is also considered here because "the micro-econometrics literature emphasizes the fixed effect model". This model permits regressors to be endogenous provided that they are correlated only with the time-invariant component of the error. Other branches of applied statistics instead, emphasize the random-effects model that assumes that regressors are completely exogenous [25].

\subsection{Model}

Fixed Effects Least-Squares Dummy Variables model according to Gujarati (2003) can mathematically be represented as follows:

$$
\begin{aligned}
Y_{i t}= & \beta_{o 1} D_{1 i}+\beta_{o 2} D_{2 i}+\beta_{o 3} D_{3 i}+\cdots+\beta_{o 10} D_{10 i}+\lambda_{1} A_{1 t}+\lambda_{2} A_{2 t} \\
& +\cdots+\lambda_{6} A_{6 t}+\beta_{1} X_{i t}+\beta_{2} X_{2 i t}^{2}+\varepsilon_{i t} ;
\end{aligned}
$$

where: $i=1,2, \cdots, 10 ; t=1,2, \cdots, 6$ and

$$
\begin{aligned}
& D_{1 i}=\left\{\begin{array}{ll}
1 & \text { if } i=1 \\
0 & \text { otherwise }
\end{array}, D_{2 i}=\left\{\begin{array}{ll}
1 & \text { if } i=2 \\
0 & \text { otherwise }
\end{array}, D_{3 i}=\left\{\begin{array}{ll}
1 & \text { if } i=3 \\
0 & \text { otherwise }
\end{array}, \cdots,\right.\right.\right. \\
& D_{10 i}= \begin{cases}1 & \text { if } i=10 \\
0 & \text { otherwise }\end{cases}
\end{aligned}
$$

These are called cross-sectional dummies that measure the uniqueness of each cross-sectional unit. Estimated coefficient of these dummies will be applied to test hypothesis two. On the other hand, the following are called time dummies that measure the effect of time (interpreted as impact of policy on motor insur- 
ance companies' outputs):

$$
A_{1 t}=\left\{\begin{array}{ll}
1 & \text { if } t=1 \\
0 & \text { otherwise }
\end{array}, A_{2 t}=\left\{\begin{array}{ll}
1 & \text { if } t=2 \\
0 & \text { otherwise }
\end{array}, \cdots, A_{6 t}= \begin{cases}1 & \text { if } t=6 \\
0 & \text { otherwise }\end{cases}\right.\right.
$$

These will however be applied to test hypothesis three.

$Y_{i t}$ : Direct Premium earned in naira (N'000);

$X_{i t}$ : Direct Claims Settlement in naira (N'000);

$\varepsilon_{i t}$ : Error associated with $Y_{i t}$

Assumption:

$$
\varepsilon_{i t} \sim N\left(0, \sigma^{2}\right) .
$$

We note that there is a quadratic term in the $X$ variable. This was determined through analysis of correlation coefficient between $Y$ and $X^{2}$. Hypothesis one will be tested using the regression coefficients of $X$ and $X^{2}$ in Equation 1. All the analyses were carried out using STATA for windows software, version 13 and all hypotheses were tested at $5 \%$ level of significance.

\section{Data Presentation and Analyses Results}

Table 1 shows that average value of premium $(Y)$ earned by the insurance firms under study for the period was N116.354 million, while claims settled $(X)$ by these firms amounted to N33.854 million on average. The standard deviations and coefficient of variations are $3.49 \times 10^{8}, 3.01 \times 10^{0}$ and $3.39 \times 10^{7}, 3.04 \times 10^{0}$ for premium earned and claims settled respectively. The Coefficient of variation shows that the variability in the $Y$ variable is $301 \%$ while that of the $X$ variable is $304 \%$. This shows that the variability in both variables is approximately the same.

Table 2 shows that $Y$ is $97 \%$ linearly correlated with $X$ and $90 \%$ linearly correlated with $X^{2}$. This suggests a parabolic or quadratic relationship between variables $X$ and $Y$.

Table 1. Descriptive statistics of pooled data.

\begin{tabular}{ccccccc}
\hline Variable & Obs. & Mean & Std. Dev. & Min & Max & CV \\
\hline$Y$ & 60 & $1.16 \mathrm{E}+08$ & $3.49 \mathrm{E}+08$ & 45726 & $1.35 \mathrm{E}+09$ & $3.01 \mathrm{E}+00$ \\
$X$ & 60 & $3.39 \mathrm{E}+07$ & $1.03 \mathrm{E}+08$ & 12604 & $4.86 \mathrm{E}+08$ & $3.04 \mathrm{E}+00$ \\
\hline
\end{tabular}

Where: Y: Direct premium earned (N’000) from 2010-2015; X: Direct Claims Settlement (N’000) from 2010-2015; CV: Coefficient of Variation.

Table 2. Correlation coefficients of ( $Y$ and $X)$ and ( $Y$ and $\left.X^{2}\right)$.

\begin{tabular}{cccc}
\hline & $Y$ & $X$ & $X^{2}$ \\
$X$ & 1.000 & & \\
& $0.972^{\star}$ & 1.000 & \\
$X^{2}$ & $(0.000)$ & & 1.000 \\
& $0.896^{*}$ & $0.970^{*}$ & \\
\hline
\end{tabular}

*Significant, p-values in parenthesis. 


\section{Tests of Hypotheses}

The following hypotheses of the study will be addressed in the sections that follow:

1) Ho: There is no significant effect of Claims Settlement on outputs (proxied by volume of premium collected) of motor insurance firms in Nigeria.

$\mathrm{H}_{1}$ : There is significant negative effect of Claims Settlement on motor insurance administration in Nigeria but increases quadratically.

Mathematically stated:

Ho: $\beta_{i}=0 ; i=1,2$;

$\mathrm{H}_{1}: \beta_{1}<0 ; \beta_{2}>0$.

2) Ho: There are no significant differences in the technological and managerial capabilities among the studied motor insurance companies in Nigeria.

$\mathrm{H}_{1}$ : There are significant differences in the technological and managerial capabilities among the studied insurance companies in Nigeria.

Mathematically stated:

Ho: $\beta_{o 1}=\beta_{o 2}=\beta_{o 3}=\cdots=\beta_{o, 10}$;

$\mathrm{H}_{1}$ : The $\beta_{\text {oi }}$ are not all equal, where $i=1,2,3, \cdots, 10$.

3) Ho: Policy changes have no significant effect on motor vehicle insurance companies' output in Nigeria over time.

$\mathrm{H}_{1}$ : Policy changes have significant effect on motor vehicle insurance companies' output in Nigeria over time.

Mathematically stated:

Ho: $\lambda_{1}=\lambda_{2}=\lambda_{3}=\cdots=\lambda_{6}$;

$\mathrm{H}_{1}$ : The $\lambda_{i}$ are not all equal, where $i=1,2,3,4,5,6$.

Using the model in 1, the three hypotheses are tested based on results in Table 3.

\section{Discussion of Results}

In Table 3, we present Fixed Effects Least Squares Dummy Variable (LSDV) regression output. Given that the F-Statistic is 388.04 with significant p-value (< $0.0000)$, the model can be considered adequate in explaining changes in output $(Y)$ of motor insurance companies in Nigeria using Claims Settlement $(X)$. Also, the $R^{2}$ and adjusted $R^{2}$ statistic values are respectively 0.9926 and 0.9896 . This means that our model of equation (1) is $99 \%$ adequate in explaining and/or predicting volume of motor insurance firms' performance in Nigeria using Claims Settlement.

Looking at the coefficient values' column (Coef. value) and rows $X$ and $X^{2}$, it is discovered that their coefficients are respectively -12.262 and $1.65 \times 10^{-8}$. They are also highly significant (see $p$-values column titled $p>|t|$ ). This is because their p-values are 0.0000 respectively. This outcome implies that $X$ (Direct Claims Paid) explains significantly volume of premium earned by motor insurance $(Y)$ companies. Simply put: If Direct Claims paid increases by N1.00, motor insurance premium will decrease by $\mathrm{N} 12.26$ and increase quadratically by N1.65 $\times 10^{-8}$. In other words it decreases by N12.26 per unit increase in $X$ or 
Table 3. Least Squares Dummy Variable (LSDV) regression model result's output.

\begin{tabular}{|c|c|c|c|c|c|c|}
\hline Coef. & Coef. value & Std. Err. & $t$ & $\mathrm{p}>|t|$ & [95\% Conf. & Interval] \\
\hline \multicolumn{7}{|l|}{ id } \\
\hline$\beta_{01}$ Niger & 2412871 & $1.89 \mathrm{E}+07$ & 0.130 & 0.899 & $-3.57 \mathrm{E}+07$ & $4.05 \mathrm{E}+07$ \\
\hline$\beta_{02}$ Cornerstone & 3904111 & $1.89 \mathrm{E}+07$ & 0.210 & 0.837 & $-3.42 \mathrm{E}+07$ & $4.20 \mathrm{E}+07$ \\
\hline$\beta_{03} \mathrm{Nem}$ & $1.39 \mathrm{E}+07$ & $1.90 \mathrm{E}+07$ & 0.730 & 0.468 & $-2.44 \mathrm{E}+07$ & $5.22 \mathrm{E}+07$ \\
\hline$\beta_{04}$ Standard & 4674357 & $1.89 \mathrm{E}+07$ & 0.250 & 0.806 & $-3.34 \mathrm{E}+07$ & $4.27 \mathrm{E}+07$ \\
\hline$\beta_{05}$ Aiico & 9461624 & $1.89 \mathrm{E}+07$ & 0.500 & 0.619 & $-2.87 \mathrm{E}+07$ & $4.76 \mathrm{E}+07$ \\
\hline$\beta_{06}$ Axa & $1.81 \mathrm{E}+07$ & $1.91 \mathrm{E}+07$ & 0.940 & 0.350 & $-2.05 \mathrm{E}+07$ & $5.67 \mathrm{E}+07$ \\
\hline$\beta_{07}$ Staco & 7847291 & $1.89 \mathrm{E}+07$ & 0.420 & 0.680 & $-3.03 \mathrm{E}+07$ & $4.59 \mathrm{E}+07$ \\
\hline$\beta_{08}$ Leadway & $2.00 \mathrm{E}+07$ & $1.92 \mathrm{E}+07$ & 1.040 & 0.303 & $-1.87 \mathrm{E}+07$ & $5.87 \mathrm{E}+07$ \\
\hline$\beta_{09}$ Mutual & 6234014 & $1.89 \mathrm{E}+07$ & 0.330 & 0.743 & $-3.18 \mathrm{E}+07$ & $4.43 \mathrm{E}+07$ \\
\hline$\beta_{10}$ Consolidated & $3.31 \mathrm{E}+09$ & $5.50 \mathrm{E}+08$ & 6.020 & 0.000 & $2.20 \mathrm{E}+09$ & $4.42 \mathrm{E}+09$ \\
\hline \multicolumn{7}{|l|}{$t$} \\
\hline$\lambda_{1(2010)}$ & $-2.14 \mathrm{E}+07$ & $1.72 \mathrm{E}+07$ & -1.250 & 0.220 & $-5.60 \mathrm{E}+07$ & $1.32 \mathrm{E}+07$ \\
\hline$\lambda_{2(2011)}$ & 723370.3 & $1.72 \mathrm{E}+07$ & 0.040 & 0.967 & $-3.39 \mathrm{E}+07$ & $3.53 \mathrm{E}+07$ \\
\hline$\lambda_{3(2012)}$ & $1.40 \mathrm{E}+07$ & $1.73 \mathrm{E}+07$ & 0.810 & 0.423 & $-2.09 \mathrm{E}+07$ & $4.89 \mathrm{E}+07$ \\
\hline$\lambda_{4(2013)}$ & -3284308 & $1.72 \mathrm{E}+07$ & -0.190 & 0.849 & $-3.79 \mathrm{E}+07$ & $3.14 \mathrm{E}+07$ \\
\hline$\lambda_{5(2014)}$ & $1.11 \mathrm{E}+07$ & $1.73 \mathrm{E}+07$ & 0.640 & 0.527 & $-2.39 \mathrm{E}+07$ & $4.61 \mathrm{E}+07$ \\
\hline$\lambda_{6(2015)}$ & 0 & (omitted) & & & & \\
\hline$X$ & -12.262 & 3.030738 & -4.050 & 0.000 & -18.37406 & -6.14993 \\
\hline$X^{2}$ & $1.65 \mathrm{E}-08$ & $3.96 \mathrm{E}-09$ & 4.160 & 0.000 & $8.49 \mathrm{E}-09$ & $2.45 \mathrm{E}-08$ \\
\hline
\end{tabular}

Model Fitting Information

No. of Observations: 60

$\mathrm{F}(17,43) 338.04$

Prob > F 0.0000

R-squared 0.9926

Adj R-squared 0.9896

Root MSE 3.7e+07

Source: Authors' data analysis. Dependent variable $Y$ : direct premium earned.

$3.59 \%$ per $1 \%$ increase in $X$. Considering the id column in Table 3, one discovers that all coefficients of the different insurance companies but Consolidated Insurance Plc. are not statistically different from zero. This therefore implies that it is only the Consolidated Insurance Plc. that exhibited significant differences in technological and managerial capabilities distinct from other companies in the study. The $t$-statistic $(\mathrm{t})$ and $\mathrm{p}$-value $(\mathrm{p}>|t|)$ columns in Table 3 show that all 
the coefficients of time are not statistically significant. This finding shows that there is no time effect (i.e. policy changes, etc.) on volume of motor vehicle insurance companies' output in Nigeria within the specified time period. Although this outcome can be explained by some factors beyond the scope of the present study, it should be noted however, that the time scope of this study coincided with the period of major political regime change in Nigeria.

\section{Conclusions}

The present research explored the time series data properties on operations of motor insurance companies in Nigeria in order to understand their performance. The major operational indices considered were the Premium earned by these companies denoted by $Y$ variable and direct claims settlement made to policyholders (denoted by $X$ ) over a period of six (6) years. Analysis of the data revealed the following:

1) Direct claim settlement negatively affected motor insurance companies' performance in Nigeria.

2) There are significant differences in the technological and managerial capabilities among the studied insurance companies in Nigeria, though only one company showed this difference.

3) There is no time effect (i.e. policy changes, etc.) on motor insurance firms' performance in Nigeria within the specified time period.

These findings underscore the fact that insurance firms should focus on effective management of earned premium and Claims settlement indices to improve performance. Specifically, intervention measures should be put in place to boost the trust of insuring public in order to increase insurance demand and hence improve earned premium. On other hand, companies should appraise every insurance risk in terms of motor characteristics before underwriting. This move would ensure that adequate premium is charged to be able to indemnify policyholders in event of loss/calamities. In terms of competence across companies studied, only one company showed a significant difference in technological and managerial capability. Again this finding is based on statistical property of panel data model but it suggests that majority of the companies evaluated have more room to improve their performance. This is understandable given that insurance companies in Nigeria are gradually going through reforms to improve their operations. The effects of these reforms have not fully been realised hence our results recorded zero policy impacts within the study period. This paper provides some insights into insurance firms' specific managerial and technological capabilities. The findings from this work can be used by insurance companies and policy administrators as metrics for gauging performance of motor insurance businesses.

\section{Recommendation}

The scope of this paper did not cover the micro and macro-economic variables 
that constitute determinants of motor insurance companies' performance. Thus, it is recommended that future studies on this theme should consider building predictive models based on economic, political and social factors that affect motor insurance firms' performance.

\section{Authors' Contributions}

Dr. G.U Ugwuanyim designed the study and participated in writing and doing the statistical analysis; Dr. D.E Onwuegbuchunam also participated in designing the study, doing the statistical analysis, wrote and edited the final paper; D.C Bartholomew contributed in the literature review and with C.C Anikpe participated in the field work for the secondary data collection.

\section{Conflicts of Interest}

The authors declare no conflicts of interest regarding the publication of this paper.

\section{References}

[1] Insurance Claims: "An Application to the Spanish Case". Research Institute of Applied Economics.

[2] Gasińska, M. (2016) Determinants of Development of Third Party Liability Insurance: Selected Approaches, Experience and Trends in Poland. Vol. 8, Foundations of Management, Vol. 8, De Gruyter, Berlin/Germany. https://doi.org/10.1515/fman-2016-0010

[3] Ryskamp, D. (2010) What Is the Role of Insurance? Demand Media, Inc., Los Angeles, USA. http://www.acls.org

[4] Augustine, O.I. and Bamidele, E.B. (2013) Employees' Empowerment and Customers' Satisfaction in Insurance Industry in Nigeria. Australian Journal of Business and Management Research, 3, 1-11.

[5] Oko, M.O. (2012) Insurance Sector Development and Economic Growth in Nigeria. African Journal of Business Management, 6, 7016-7023.

http://www.academicjournals.org/AJBM https://doi.org/10.5897/AJBM11.2853

[6] Research and Market (2009) Nigerian Insurance Report. http://www.reportlink.com

[7] KPMG International Ltd. (2012) Sector Report Insurance in Africa. http://www.kpmg.com/africa

[8] Cheruiyot, J.R. (2015) Challenges in the Uptake of Marine Cargo Insurance in Kenya. Unpublished MBA Thesis, University of Nairobi, Nairobi. http://erepository.uonbi.ac.ke/bitstream/handle/11295/93202/Rono\%2c\%20Cheruiy ot\%20J_marine\%20cargo\%20insurance\%20in\%20Kenya.pdf? sequence $=4$ \&isAllowe $\mathrm{d}=\mathrm{y}$

[9] Adewale, M. (2015) New Government, New Life, New Hope: For Maritime Industry, a Better Nigeria. Nigerian Tribune. http://webcache.googleusercontent.com

[10] Nigeria Insurance Association NIA (2016) Insurance Report. https://www.nigeriainsurers.org/downloads

[11] Cummins, D.J. and Venard, B. (2008) Insurance Market Dynamics: Between Global Developments and Local Contingencies. 
https://doi.org/10.1111/j.1540-6296.2008.00142.x

[12] Satish, K. (2019) The Dynamics of General Insurance Sector in India-Growth and Performance Perspective. International Journal of Engineering and Advanced Technology, 9, 536-540. https://doi.org/10.35940/ijeat.B3261.129219

[13] Ofori-Attah, H.E.B. (2012) The Effects of Slow Claims Settlement on the Sales and Marketing of Insurance Products; a Case Study of Enterprise Insurance Co. Ltd. (Eic)-Takoradi Branch. An M.Sc. Thesis, Institute of Distance Learning, Kwame Nkrumah University of Science and Technology, Kumasi.

[14] Yusuf, T.O., Ajemunigbohun, S.S. and Alli, G.N. (2017) A Critical Review of Insurance Claims Management: A Study of Selected Insurance Companies in Nigeria. SPOUDAI Journal of Economics and Business, 67, 69-84.

[15] Santolino, M. and Boucher, J.P. (2009) Modeling the Disability Severity Score in Motor Insurance Claims: An Application to the Spanish Case. Working Paper, Research Institute of Applied Economics, University of Barcelona, Spain. https://www.researchgate.net/publication/23935289

[16] Singh, V. (2012) Global Trends in Non-Life Insurance: Claims. Capgemini.

[17] Rose, S. (2013) Predictive Claims Processing: Transforming the Insurance Claims Life Cycle Using Analytics. SAS White Paper, 1-8.

[18] Yong, J. (2020) Insurance Regulatory Measures in Response to Covid-19. Financial Stability Institute, Basel, Switzerland. http://www.bis.org

[19] Kumaga, B.S., Kuttu, S. and Asuming, P.O. (2016) Determinants of Comprehensive Motor Insurance Demand: Evidence from the Recent Premium Tariff Increase in Ghana. Unpublished M. Phil. Thesis, The University of Ghana, Legion. http://Ugspace.Ug.Edu.Gh

[20] Sukono, R., Lesmana, E., Wulandari, R., Napitupulu, H. and Supian, S. (2018) Model Estimation of Claim Risk and Premium for Motor Vehicle Insurance by Using Bayesian Method. IOP Conference Series: Materials Science and Engineering, 300, Article ID: 012027. https://doi.org/10.1088/1757-899X/300/1/012027

[21] Segovia-Vargas, M., Camacho-Miñano, M. and Pascual-Ezama, D. (2015) Risk Factor Selection in Automobile Insurance Policies: A Way to Improve the Bottom Line of Insurance Companies. Review of Business Management, São Paulo, 17, 1228-1245. https://doi.org/10.7819/rbgn.v17i57.1741

[22] Oshinloye, M.O. (2009) The Impact of Insurance Activities on Economic Growth. Sun Newspaper, June 10, 2014.

[23] Wairimu, K.M. (2010) Challenges in Management of General Insurance Claims in Kenya. A Management Research Project Submitted in Partial Fulfillment of the Requirements for the Award of the Degree of Master of Business Administration, School of Business, University of Nairobi, Nairobi.

[24] Onwuegbuchunam, D.E., Igboanusi, C. and Ogwude, I.C. (2017) The Performance of Marine Insurance Firms in Nigeria: An Augmented SWOT Analysis. International Journal of Transportation Engineering and Technology, 3, 83-90. https://doi.org/10.11648/j.ijtet.20170304.16

[25] Cameron, A.C. and Trivedi, P.K. (2009) Microeconomics Using Stata. State Press, Texas, USA.

[26] Gujarati, D.N. (2003) Basic Econometrics. 4th Edition, McGraw Hill, New York. 